\title{
CHEMICAL DESICCANTS FOR ANTICIPATION OF HARVEST AND PHYSIOLOGICAL QUALITY OF COWPEA SEEDS ${ }^{1}$
}

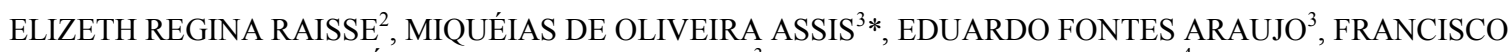 \\ CLÁUDIO LOPES DE FREITAS ${ }^{3}$, ROBERTO FONTES ARAUJO ${ }^{4}$
}

\begin{abstract}
Information about the effect of herbicides on cowpea seed quality is scarce. The objective of this work was to evaluate the effect of using chemical desiccants at pre-harvest on the anticipation of harvest and physiological quality of cowpea seeds of the cultivar BRS-Tumucumaque, before and after storage. Two experiments were conducted: experiment 1 was conducted under a randomized block design, with four replications; the treatments consisted of seven herbicides (carfentrazone-ethyl, saflufenacil, glyphosate, paraquat, flumioxazin, glufosinate-ammonium, and diquat) and a control treatment; anticipation of harvest, and seed water content, germination, and vigor were evaluated. The seeds were stored for six months in controlled environment and not-controlled environment rooms and evaluated for water content, germination, and vigor in Experiment 2, which was conducted in a $7 \times 2+1$ factorial arrangement, with four replications; the first factor consisted of the seven herbicides, the second factor was the two storage environments, plus a control treatment. The results showed 3 to 9 days of anticipation of harvest relative to the control. The glufosinate-ammonium herbicide negatively affected seed germination and vigor. The glyphosate herbicide decreased seed germination and vigor after storage. The physiological quality of cowpea seeds at the post-harvest period and after six months of storage was not affected by the carfentrazone-ethyl and flumioxazin herbicides. Paraquat and diquat were the most efficient herbicides for the anticipation of harvest (nine days). Glyphosate and glufosinateammonium were the most harmful herbicides to seed physiological quality. The controlled environment room was the most adequate environment for seed conservation.
\end{abstract}

Keywords: Vigna unguiculata. Desiccation. Germination. Vigor. Storage.

\section{EFEITO DE DESSECANTES QUÍMICOS NA ANTECIPAÇÃO DA COLHEITA E QUALIDADE FISIOLÓGICA DE SEMENTES DE FEIJÃO-CAUPI}

\begin{abstract}
RESUMO - São escassas as informações sobre o efeito de herbicidas sobre a qualidade sementes de feijãocaupi. Objetivou-se avaliar o efeito de dessecantes químicos na pré-colheita sobre a antecipação da colheita e qualidade fisiológica das sementes de feijão-caupi Cv BRS Tumucumaque, antes e após o armazenamento. No experimento 1, adotou-se o delineamento de blocos casualizados, com quatro repetições. Os tratamentos foram: sete herbicidas (carfentrazone-ethyl, saflufenacil, glyphosate, paraquat, flumioxazin, amonio-glufosinate e diquat) e um tratamento controle. Avaliou-se a antecipação de colheita, teor de água, germinação e vigor das sementes. As sementes foram armazenadas por seis meses em sala climatizada e ambiente não controlado e avaliadas quanto ao o teor de água, germinação e vigor, compondo o experimento 2, que foi disposto em esquema fatorial $7 \times 2+1$, com quatro repetições. O primeiro fator correspondeu a sete herbicidas, o segundo a dois ambientes de armazenamento, mais um tratamento controle. Observou-se um período de 3 a 9 dias de antecipação da colheita em relação a testemunha. O amônio-glufosinate afeta negativamente a germinação e o vigor das sementes. Após o armazenamento, menor germinação e vigor foram observados para o herbicida glyphosate. Os herbicidas carfentrazone-ethyl e flumioxazin não afetaram a qualidade fisiológica das sementes de feijão caupi nos períodos pós-colheita e seis meses após o armazenamento. O paraquat e o diquat foram os herbicidas mais eficientes na antecipação da colheita (nove dias). O glyphosate e o amonio-glufosinate foram os herbicidas mais prejudiciais à qualidade fisiológica das sementes. A sala climatizada é o ambiente mais adequado para conservação das sementes.
\end{abstract}

Palavras-chave: Vigna unguiculata. Dessecação. Germinação. Vigor. Armazenamento.

\footnotetext{
${ }^{*}$ Corresponding author

${ }^{1}$ Received for publication in $09 / 18 / 2019$; accepted in $05 / 20 / 2020$.

Paper extracted from the master thesis of the first author.

${ }^{2}$ Instituto de Investigação Agrária de Moçambique, Nampula province, Mozambique; elizethreginar@yahoo.com.br - ORCID: 0000-00031478-0864.

${ }^{3}$ Department of Agronomy, Universidade Federal de Viçosa, Viçosa, MG, Brazil; miqueias.assis@ufv.br - ORCID: 0000-0001-9807-9586, efaraujo@ufv.br - ORCID: 0000-0003-0004-4188, francisco.freitas@ufv.br-ORCID: 0000-0003-1911-7201.

${ }^{4}$ Empresa de Pesquisa Agropecuária de Minas Gerais, Viçosa, MG, Brazil; roberto.araujo@epamig.br - ORCID: 0000-0002-2625-5365.
} 


\section{INTRODUCTION}

Cowpea [Vigna unguiculata (L.) Walp] is a legume species native to West and Central Africa that was introduced to Brazil in the mid- $16^{\text {th }}$ century. Cowpea crops have been expanded to specialized agricultural regions of the country, especially the Central-West, where they started to be grown at large scale in 2006 (FREIRE FILHO et al., 2017). This expansion was due to the development of varieties with early and uniform maturation cycles for mechanized crop systems, and breeding for high grain quality (ROCHA et al., 2017).

The expansion of the planting area and the development of technologies for cowpea crops increased the demand for high quality seeds, since it is essential for a successful establishment of the crop in different environmental conditions.

When intending to produce high-quality seeds, the seeds should be harvested when they reach the physiological maturity point, which is the stage when they have maximum accumulation of dry matter and the greatest physiological potential. However, mechanized harvest is technically and economically unviable because cowpea seeds present approximately $54 \%$ water content at this point (NOGUEIRA et al., 2014) and are not suitable for mechanized harvesting because of the high number of plants with green leaves and stems.

However, delaying the harvest may result in decreased seed viability due to the prolonged exposure of seeds to unfavorable edaphoclimatic conditions and the incidence of pests and diseases.

The use of desiccant herbicides at pre-harvest has been an important strategy to minimize the deterioration of seeds in the field. This practice enables the anticipation of harvest, facilitates the mechanized harvest of seeds, and promotes maturation uniformity for species with indeterminate growth habit, without causing losses in seed yield, germination, and vigor. Positive results of preharvest desiccation were found for seeds of cowpea (ASSIS et al., 2019), rice (HE et al., 2015), common bean (MCNAUGHTON et al., 2015; TAVARES et al., 2016), soybean (KAPPES et al., 2012; SANTOS et al., 2018), and wheat (JASKULSKI; JASKULSKA, 2014).

Paraquat has been the main herbicide used in Brazil for desiccation of crops at pre-harvest (LAMEGO et al., 2013). However, this molecule is in process of discontinuity (BRASIL, 2017). Therefore, studies using other molecules and focused on recommendation of herbicides that enable the anticipation of harvest without affecting seed quality are important.

The available scientific literature includes some works about the effect of herbicide application at pre-harvest on the physiological quality of seeds (ASSIS et al., 2019; HUBNER JUNIOR; TOLEDO, 2016). However, evaluations on the latent effect of pre-harvest desiccation on the physiological quality of seeds are still scarce.

In this context, the objective of this work was to evaluate the effect of herbicides at pre-harvest on the anticipation of harvest and physiological quality of cowpea seeds before and after storage.

\section{MATERIAL AND METHODS}

\section{Experiment 1}

A field and a laboratory experiment were conducted from January to May 2018. The seed were sowed in areas under no-tillage system for seed production on January 31, 2018, using a seeder tractor set to distribute 10 seeds per meter to a depth of 3 to $4 \mathrm{~cm}$. Each experimental unit (plot) consisted of five 5-meter rows spaced $0.5 \mathrm{~m}$ apart. The evaluation area consisted of the three central rows, discarding $0.5 \mathrm{~m}$ from each end. Soil fertilization at planting was based on soil chemical analysis, using $150 \mathrm{~kg} \mathrm{ha}^{-1}$ of the N-P-K formulation $8: 28: 16$. The cowpea seeds used were from the cultivar BRSTumucumaque, which have early-maturation cycle and semi-erect growth habit (OLIVEIRA et al., 2014).

The rainfall depths, mean, maximum, and minimum air temperatures, and relative air humidity during the field experiment are presented in Figure 1; the mean relative air humidity was $83.5 \%$.

The herbicides were applied when $55 \%$ of the plant pods were at the physiological maturity stage (R4), using a $\mathrm{CO}_{2}$-pressurized backpack sprayer equipped with four flat-jet nozzles (XR 110-02; Teejet ${ }^{\circledR}$, Wheaton, USA) spaced $0.5 \mathrm{~m}$ apart. The solutions were applied with a pressure of $200 \mathrm{kPa}$, volume of $220 \mathrm{~L} \mathrm{ha}^{-1}$, between $08: 00 \mathrm{~h}$ and 09:00h; the climatic conditions were monitored using a portable digital thermo-hygro-anemometer, which showed mean air temperature, relative air humidity, and wind speed of $24.4{ }^{\circ} \mathrm{C}, 62.5 \%$, and $4 \mathrm{~km} \mathrm{~h}^{-1}$, respectively.

A randomized block design was used, with four replications. The treatments consisted of seven herbicides (Table 1) and a control treatment with no herbicide application. 


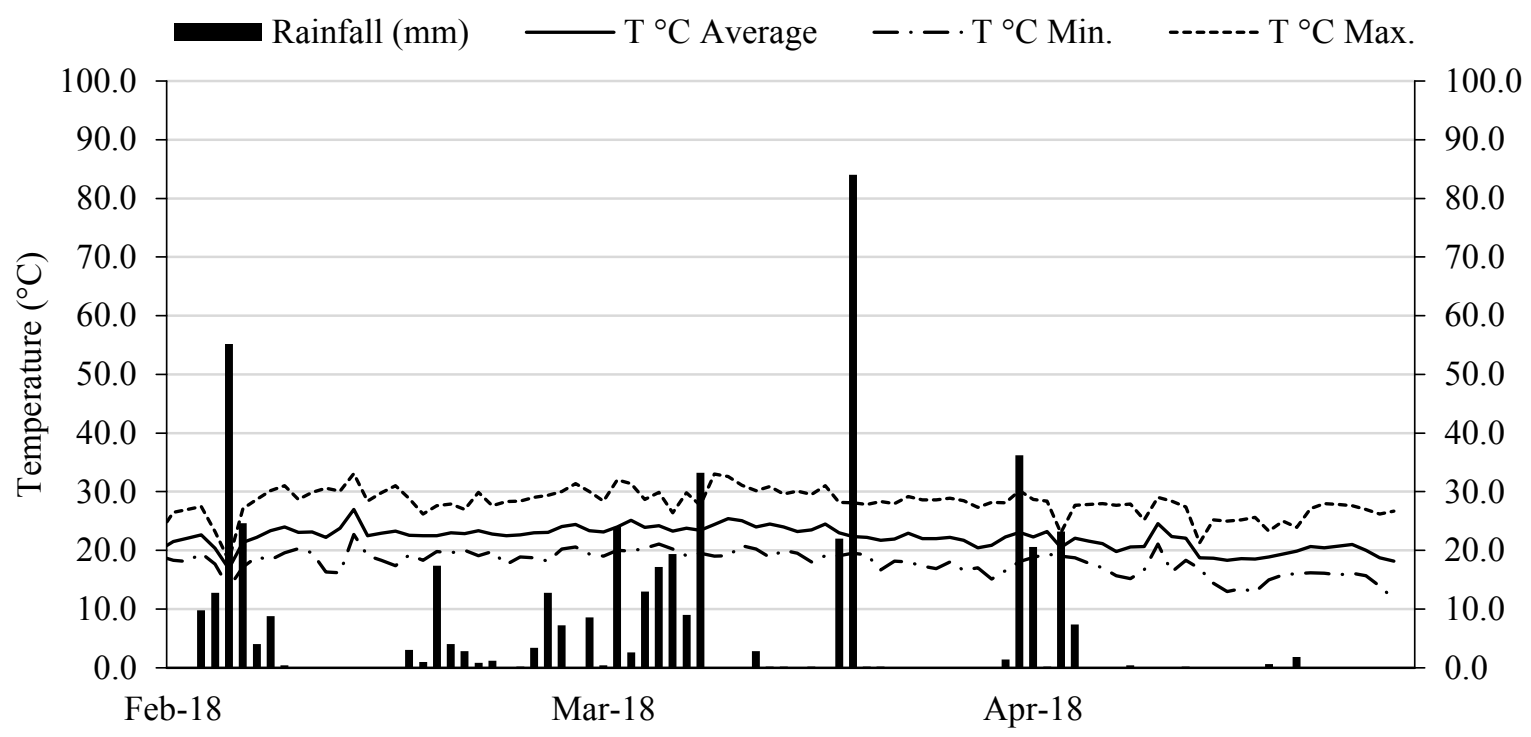

Figure 1. Daily rainfall depths, mean, maximum, and minimum air temperature, and relative air humidity throughout the field experiment. Viçosa, MG, Brazil, 2018. Source: INMET (2018).

Table 1. Herbicides and rates used.

\begin{tabular}{|c|c|c|c|}
\hline Active ingredient & Commercial product & $\begin{array}{l}\text { Commercial } \\
\text { product rate }\end{array}$ & $\begin{array}{l}\text { Active ingredient (a.i.)/acid } \\
\text { equivalent (a.e.) rate }\end{array}$ \\
\hline Carfentrazone-ethyl & Aurora $\AA$ & $125 \mathrm{~mL} \mathrm{ha}^{-1}$ & $* 50.0$ g a.i. ha $^{-1}$ \\
\hline Flumioxazin & Flumyzin500® & $50 \mathrm{~g} \mathrm{ha}^{-1}$ & $* 25.0$ g a.i. ha $^{-1}$ \\
\hline Saflufenacil & Heat $\AA$ & $125 \mathrm{~g} \mathrm{ha}^{-1}$ & $87.5 \mathrm{~g}$ a.i. $\mathrm{ha}^{-1}$ \\
\hline Glyphosate & Roundup original ${ }^{\circledR}$ & $4 \mathrm{~L} \mathrm{ha}^{-1}$ & 1480 g. a.e. ha ${ }^{-1}$ \\
\hline Paraquat & Gramoxone $\AA$ & $2 \mathrm{~L} \mathrm{ha}^{-1}$ & 400.0 g a.i. $\mathrm{ha}^{-1}$ \\
\hline Diquat & Reglone $\AA$ & $2 \mathrm{~L} \mathrm{ha}^{-1}$ & 400.0 g a.i. $^{-1}$ \\
\hline Glufosinate-ammonium & Finale $\AA$ & $2 \mathrm{~L} \mathrm{ha}^{-1}$ & $* * 400.0 \mathrm{~g}$ a.i. $\mathrm{ha}^{-1}$ \\
\hline
\end{tabular}

$* 0.5 \%\left(\mathrm{v} \mathrm{v}^{-1}\right)$, and $* * 0.2 \%\left(\mathrm{v} \mathrm{v}^{-1}\right)$ of mineral oil were added to the solution.

The seed water content was monitored within three days after the application of the herbicides; plants were collected randomly in the field and taken to the laboratory where the pods were manually threshed; then, the seeds were dried in an oven at $105 \pm 3{ }^{\circ} \mathrm{C}$ for 24 hours to determine their water content (BRASIL, 2009). The plants were manually harvested by pluck them when the seeds reached water content of approximately $18 \%$.

The time of anticipation of harvest was determined by the number of days between the herbicide application and the harvest, considering the time the plants in the treatment without desiccant application (control) were suitable for harvesting.

The seeds were then taken to the laboratory for the following evaluations:

Germination test: four replications of 50 seeds were used; the seeds were germinated in paper rolls (Germitest) moistened with distilled water (2.5-fold the weight of the paper roll). The paper rolls were placed in plastic bags and maintained in a BOD chamber at constant temperature $\left(30^{\circ} \mathrm{C}\right)$. The normal seedlings were counting after eighth days, and the results were expressed as percentages of normal seedlings (BRASIL, 2009).

First germination counting: conducted together with the germination test by evaluating the number of normal seedlings after five days; the results were expressed as percentages of normal seedlings (BRASIL, 2009).

Seedling emergence: evaluated in a seedling growth room using four replications of 50 seeds, which were sown to a depth of $3 \mathrm{~cm}$ in expanded polystyrene trays containing washed sterilized sand. The plants were irrigated when needed, using sprayers. The emerged seedlings were counted at 8 days after sowing. The seedlings that presented totally expanded cotyledons above the substrate were accounted. The results were expressed as percentages.

Emergence speed index: evaluated together with the emergence test, by daily counting of emerged seedlings (totally expanded cotyledons above the substrate) up to the stabilization of the emergence. The emergence speed index of the seedlings was calculated according to Maguire 
(1962).

Accelerated aging: evaluated using four replications of 50 seeds, which were distributed in a single layer on a stainless-steel screen, and placed in plastic boxes (Gerbox), containing $40 \mathrm{~mL}$ of distilled water. The seeds were maintained in a BOD chamber at constant temperature $\left(42{ }^{\circ} \mathrm{C}\right)$ for 48 hours (DUTRA; TEÓFILO, 2007). The seeds were evaluated by germination test, with evaluation of normal seedlings at 5 days after the test implementation. The germination test was conducted as previously described.

Electrical conductivity: evaluated using four replications of 50 seeds, which were weighed, subjected to imbibition in a container containing 75 $\mathrm{mL}$ of water deionized, and maintained in a germinator at constant temperature $\left(25^{\circ} \mathrm{C}\right)$ for 24 hours (DUTRA et al., 2006). The electrical conductivity of the seed imbibition solution was then read using a digital conductivity meter; the results were expressed as $\mu \mathrm{S} \mathrm{cm}^{-1} \mathrm{~g}^{-1}$.

The data were evaluated for normality
(Shapiro-Wilk test) and homogeneity of variance (Oneill and Mathews test) at $p<0.05$ and, then, subjected to analysis of variance. The means were compared by the Scott-Knott test $(p<0.05)$, and the control treatment was compared to the other treatments by the Dunnett's test $(p<0.05)$.

\section{Experiment 2}

Experiment 2 was conducted after experiment 1 ; the seeds were placed in permeable Kraft paper bags with capacity for $1 \mathrm{~kg}$ and stored for six months (May to November 2018), under two environments: controlled environment room, with mean temperature of $20{ }^{\circ} \mathrm{C}$ and relative humidity of approximately $55 \%$, and not-controlled environment, with temperature and relative air humidity varying during the storage period (Figure 2). The water content, germination, and vigor (first germination count, seedling emergence, accelerated aging, and electrical conductivity) of seeds were determined after the storage period.

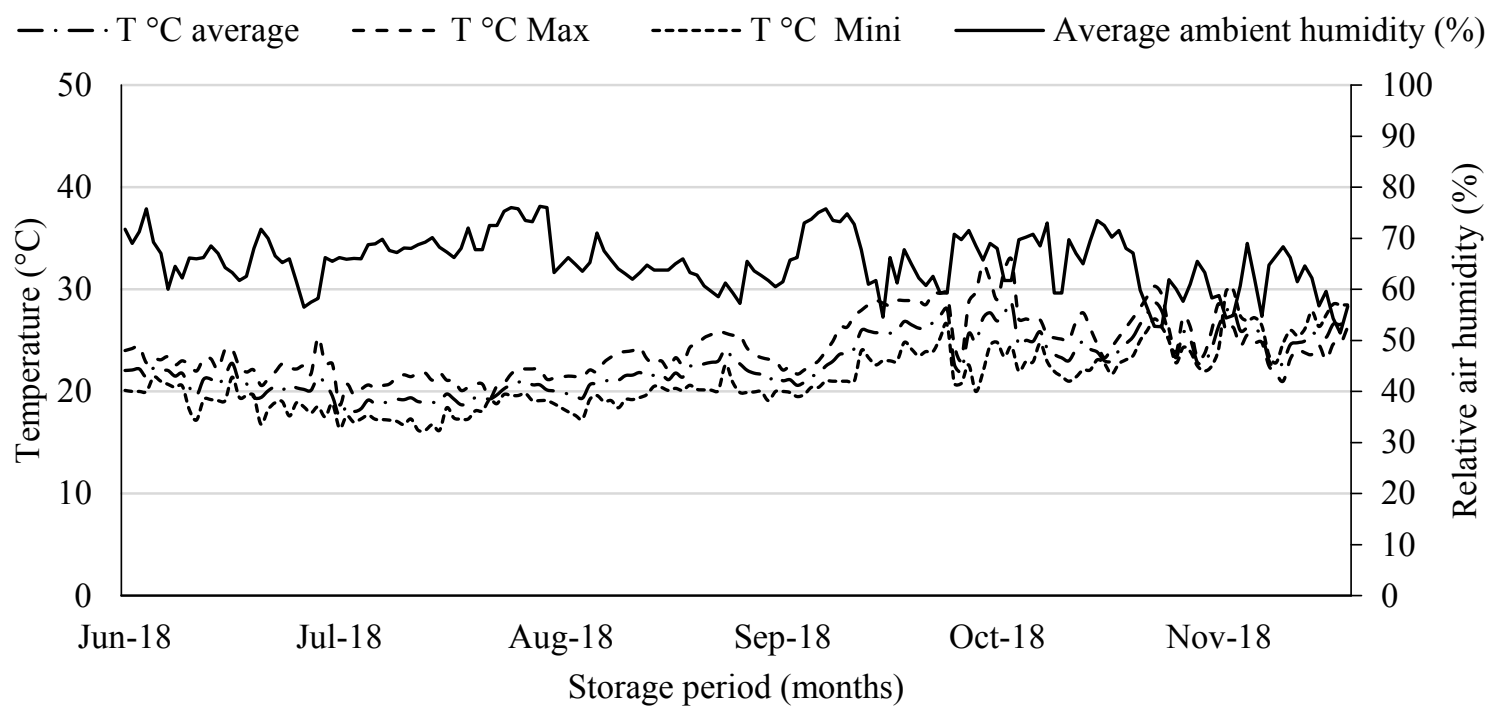

Figure 2. Daily mean, maximum, and minimum air temperature, and relative air humidity throughout the storage period of cowpea seeds (BRS-Tumucumaque) in the not-controlled environment.

A randomized block design was used, with four replications. The treatments were arranged in a $7 \times 2+1$ factorial arrangement: the first factor consisted of seven herbicides (Table 1), plus a control without herbicides application, and the second factor consisted of two storage environments (controlled environment, and not-controlled environment). The data were evaluated for normality (Shapiro-Wilk test) and homogeneity of variance (Oneill and Mathews test) at $p<0.05$ and, then, subjected to analysis of variance. When the interaction between herbicides and storage environments was significant $(p<0.05)$, the means were compared by the Scott-Knott test $(p<0.05)$, and the control treatment was compared to the other treatments by the Dunnett's test $(p<0.05)$.

\section{RESULTS AND DISCUSSION}

\section{Experiment 1}

The use of pre-harvest desiccation enables the anticipation of harvest of cowpea seeds. The chemical desiccation of the plants decreased the seed water content to suitable levels for mechanized 
harvest (18\%) at 3 to 9 days before the harvest of the control treatment (Table 2). The longest time (9 days) of anticipation of harvest was found for the treatments with paraquat and diquat. Flumioxazin, saflufenacil, and glufosinate-ammonium herbicides anticipated the harvest in 6 days. The shortest time of anticipation of harvest was found for the glyphosate and carfentrazone-ethyl herbicides (3 days).

Table 2. Seed water content at harvest and time of anticipation of harvest resulted from application of desiccants for cowpea plants (BRS-Tumucumaque) relative to the control.

\begin{tabular}{ccc}
\hline Herbicides & Water content (\%) & Anticipation of harvest (days) \\
\hline Carfentrazone-ethyl & 15.6 & 3 \\
Flumioxazin & 18.0 & 6 \\
Saflufenacil & 17.0 & 6 \\
Glyphosate & 17.5 & 3 \\
Paraquat & 17.8 & 9 \\
Diquat & 17.6 & 9 \\
Glufosinate-ammonium & 18.0 & 6 \\
\hline Control & 16.5 & 0 \\
\hline
\end{tabular}

Anticipation of harvest is essential for production of seeds. The early removal of seeds from the field minimizes risks of exposing them to unfavorable biotic and abiotic factors, and ensures the harvest of seeds with high physiological potential (TERASAWA et al., 2009). However, anticipating the harvest may hinder the performance of seeds due to their maturation, since they may not be fully formed and have low dry matter accumulation (PELÚZIO et al., 2008). This can result in low-vigor seeds, because an incomplete seed formation may increase their sensitivity to deterioration (MARCOS FILHO, 2015).

Assis et al. (2019) found that pre-harvest desiccation anticipates the harvest of cowpea seeds in up to 13 days. Lacerda et al. (2001) found anticipation of up to seven days in the harvest of soybean seeds after desiccation, without change the production. Domingos et al. (1997) found that the application of herbicides anticipated the harvest of common bean seeds of the cultivar Carioca in up to 13 days.

The times of anticipation of harvest after application of herbicides may be different from one region to another. Longer times of anticipation of harvest can be found for regions with milder climate when compared to regions of with high mean temperatures where the natural drying of plants is faster, making the anticipation of harvest less pronounced (LACERDA et al., 2001).

The time of anticipation resulted from the use of the herbicides varied according to mode of action of each herbicide (Table 2). The herbicides paraquat and diquat presented longer time of anticipation of harvest (9 days) relative to the control. These herbicides are non-selective (contact) herbicides, with low translocation in the plant; they are photosystem I inhibitors and, when absorbed, work as false acceptors, deflecting the electron flow. This interruption paralyzes the reduction of ferredoxin and the subsequent reactions. The phytotoxicity symptoms are rapidly shown (2 hours after application), and the plant may be dead within two days (OLIVEIRA JÚNIOR, 2011).

Although similar to paraquat and diquat, the evolution of the symptoms caused by Protox inhibitor herbicides (carfentrazone-ethyl, flumioxazin, and saflufenacil) are slower (HESS, 2000). This probably decreased the time of anticipation of harvest of these herbicides when compared to paraquat and diquat. The mechanism of action of these herbicides consists of inhibiting the metabolic route of the protoporphyrinogen oxidase enzyme (Protox) synthesis, which indirectly affects chlorophyll synthesis (TORRES et al., 2012).

The glyphosate herbicide enabled the anticipation of harvest in up to 3 days; however, it is a systemic herbicide that requires up to six hours to be absorbed (MARTINI et al., 2003). After absorbed, its translocation to other plant organs occurs after approximately five days (FERREIRA et al., 2006). The development of the symptoms is usually slow, with gradual emergence of chlorosis and necrosis. Susceptible plants may be dead at 7 to 30 days after herbicide application, depending on the plant species and development stage and herbicide rate applied (SILVA et al., 2007).

The quality of seeds produced may be benefited, despite the anticipation of harvest of only 3 days, mainly when there is a risk of occurrence of rainfall before the harvest or attack of pests or microorganisms.

The results of all variables considered to evaluate the physiological quality of cowpea seeds 
from desiccated plants at pre-harvest decreased, relative to the control, when using glufosinateammonium. (Table 3). Lacerda et al. (2003) and Guimarães et al. (2012) also found that the use of glufosinate-ammonium for the desiccation of soybean plants affected negatively the quality of seeds relative to the control.

The glufosinate-ammonium herbicide has easier translocation than paraquat, despite it is a contact herbicide (LACERDA et al., 2005), which may have resulted in more significant decreases in seed physiological quality. According to McNaughton et al. (2015), the application of glufosinate-ammonium herbicide at pre-harvest is not recommended because residues of the herbicide may be found on beans. However, Assis et al. (2019) found no negative effect of this desiccant herbicide on cowpea seed quality after pre-harvest desiccation.

Table 3. Germination (GE), first germination counting (FGC), emergence (EM), emergence speed index (ESI), accelerated aging (AA), and electrical conductivity (EC) of cowpea seeds (BRS-Tumucumaque) from of plants subjected to pre-harvest herbicides application.

\begin{tabular}{ccccccc}
\hline Herbicides & GE (\%) & FGC (\%) & EM (\%) & ESI & AA (\%) & $\begin{array}{c}\text { EC } \\
\left(\mu \mathrm{Scm}^{-1} \mathrm{~g}^{-1}\right)\end{array}$ \\
\hline Carfentrazone-ethyl & $87.0 \mathrm{~A}$ & $86.0 \mathrm{~A}^{*}$ & $86.0 \mathrm{~A}$ & $9.3 \mathrm{~A}$ & $71.0 \mathrm{~A}$ & $129.3 \mathrm{~A}$ \\
Flumioxazin & $81.0 \mathrm{~A}$ & $74.0 \mathrm{~B}$ & $89.5 \mathrm{~A}$ & $9.5 \mathrm{~A}$ & $78.0 \mathrm{~A}$ & $121.5 \mathrm{~A}$ \\
Saflufenacil & $78.0 \mathrm{~A}$ & $76.0 \mathrm{~B}$ & $87.5 \mathrm{~A}$ & $9.3 \mathrm{~A}$ & $76.0 \mathrm{~A}$ & $119.0 \mathrm{~A}$ \\
Glyphosate & $70.5 \mathrm{~B}^{*}$ & $70.5 \mathrm{C}^{*}$ & $73.0 \mathrm{~B} *$ & $9.0 \mathrm{~A}$ & $68.0 \mathrm{~A}$ & $136.0 \mathrm{~B}^{*}$ \\
Paraquat & $89.0 \mathrm{~A}$ & $87.0 \mathrm{~A}^{*}$ & $86.0 \mathrm{~A}$ & $9.3 \mathrm{~A}$ & $72.0 \mathrm{~A}$ & $134.4 \mathrm{~B}^{*}$ \\
Diquat & $81.0 \mathrm{~A}$ & $79.0 \mathrm{~B}^{*}$ & $86.5 \mathrm{~A}$ & $9.0 \mathrm{~A}$ & $38.5 \mathrm{C}^{*}$ & $126.0 \mathrm{~A}$ \\
Glufosinate-ammonium & $67.0 \mathrm{~B}^{*}$ & $62.0 \mathrm{C}^{*}$ & $74.5 \mathrm{~B}^{*}$ & $7.7 \mathrm{~B}^{*}$ & $57.0 \mathrm{~B}^{*}$ & $147.3 \mathrm{~B}^{*}$ \\
\hline Control & 82.0 & 80.0 & 90.0 & 10.0 & 82.0 & 120.0 \\
\hline CV (\%) & 8.26 & 7.61 & 8.03 & 7.74 & 14.82 & 8.94 \\
\hline
\end{tabular}

*different from the control treatment by the Dunnett's test $(p<0.05)$. Means followed by the same letter in the columns are not different by the Scott-Knott test $(p<0.05)$.

The glyphosate herbicide negatively affected the germination (GE), first germination counting (FGC), emergence (EM), and electrical conductivity (EC) of cowpea seeds, relative to the control. Zuffo et al. (2019), Toledo et al. (2014), Marcandalli et al. (2011), and Daltro et al. (2010) found losses in soybean seed quality after pre-harvest desiccation with glyphosate herbicide due to its systematicity which, combined with the uneven maturation of the cultivar, may have caused the translocation of the herbicide to seeds still in formation, negatively affecting the seed quality (MARCANDALLI et al., 2011).

Zhang et al. (2016) reported that the seed water content at the time of application can affect the translocation of glyphosate to the seeds.

The use of the carfentrazone-ethyl, flumioxazin, saflufenacil, diquat, and paraquat resulted in higher GE and EM than the use of glyphosate and glufosinate-ammonium (Table 3). Guimarães et al. (2012) found similar results for soybean seeds from plants of the cultivar BRS-184 desiccated with glyphosate and glufosinateammonium, which presented lower germination than those desiccated using paraquat. The glyphosate and glufosinate-ammonium herbicides may have been absorbed, since they were sprayed directly on the pods, which, in cowpea plants of the cultivar BRS-
Tumucuma, are located above the leaves. Despite glufosinate-ammonium is classified as a contact herbicide, it has better translocation inside the plant than paraquat (LACERDA et al., 2005).

The results of the seed germination test for plants desiccated with carfentrazone-ethyl, flumioxazin, saflufenacil, diquat, and paraquat herbicides were above the minimum $(80 \%)$ required to market the product as seeds (BRASIL, 2013).

Regarding the vigor of the seeds, the results for FGC showed that the pre-harvest desiccation with carfentrazone-ethyl and paraquat resulted in more vigorous seeds than the other treatments. Intermediate vigor was found for flumioxazin, saflufenacil, and diquat, and low vigor was found for glyphosate and glufosinate-ammonium (Table 3).

Lower emergence speed index (ESI) was found for seeds from plants desiccated with glufosinate-ammonium when compared to the other herbicides, which presented similar results to each other (Table 3).

The accelerated aging (AA) test showed that the desiccation with diquat resulted in the lowest seed vigor, followed by glufosinate-ammonium; the other treatments presented no significant differences from each other (Table 3 ).

The EC test showed that glufosinateammonium, paraquat, and glyphosate presented 
higher leaching of exudates. The EC found for the other herbicides varied from 119.0 to $129.3 \mu \mathrm{Scm}^{-1} \mathrm{~g}^{-1}$, but were not significantly different (Table 3).

According to Botelho et al. (2016), preharvest desiccation can affect the seed vigor probably because of the effect of herbicides on the integrity of seed cell membranes, affecting the solute release rate, which is indirectly detected by the electrical conductivity test. This decreases the capacity of reorganization of membranes, resulting in a higher loss of solutes to the environment and in seeds with lower uniformity and germination speed and stimulating the development of pathogenic microorganisms (MARCOS FILHO, 2015).

\section{Experiment 2}

The water content of cowpea seeds presented no significant differences after six months of storage, varying from $11 \%$ to $12 \%$.

The interaction between herbicides and storage environments was not significant. Despite the experiment had been conducted in different environments, the mean temperatures of the controlled environment $\left(20^{\circ} \mathrm{C}\right)$ and not-controlled environment $\left(22.1{ }^{\circ} \mathrm{C}\right)$ rooms (Figure 2) were similar, which is probably related to the nonsignificance of the herbicide-storage environment interaction for seed quality.

Glyphosate was the most harmful herbicide to the physiological quality of cowpea seeds after their storage, resulting in lower seed quality relative to the control, except for EC, which showed no differences between herbicides (Table 4). Daltro et al. (2010) reported that the negative action of glyphosate on the physiological potential of seeds is clear, mainly for cultivars that have no resistance to this product.

Negative effects were also found for the diquat herbicide, which presented lower results than the control treatment for the variables GE, FGC, EM, and AA (Table 4). In addition, Botelho et al. 2016 found that the physiological quality of soybean seeds after six months of storage decreased because of the use of diquat for pre-harvest desiccation.

Table 4. Germination (GE), first germination counting (FGC), emergence (EM), emergence speed index (ESI), and accelerated aging (AA), and electrical conductivity (EC) of cowpea seeds from plants of the cultivar BRS-Tumucumaque subjected to application of herbicides at pre-harvest, after six months of storage.

\begin{tabular}{ccccccc}
\hline Herbicides & $\begin{array}{c}\text { GE } \\
(\%)\end{array}$ & $\begin{array}{c}\text { FGC } \\
(\%)\end{array}$ & $\begin{array}{c}\text { EM } \\
(\%)\end{array}$ & ESI & $\begin{array}{c}\text { AA } \\
(\%)\end{array}$ & $\begin{array}{c}\text { EC } \\
\left(\mu \mathrm{Scm}^{-1} \mathrm{~g}^{-1}\right)\end{array}$ \\
\hline Carfentrazone-ethyl & $82.5 \mathrm{~A}$ & $81.0 \mathrm{~A}$ & $86.0 \mathrm{~B}$ & $9.9 \mathrm{~A}^{*}$ & $81.5 \mathrm{~A}$ & $120.0 \mathrm{~A}$ \\
Flumioxazin & $82.0 \mathrm{~A}$ & $81.0 \mathrm{~A}$ & $90.0 \mathrm{~A}^{*}$ & $10.5 \mathrm{~A}^{*}$ & $78.0 \mathrm{~A}$ & $115.0 \mathrm{~A}$ \\
Saflufenacil & $70.0 \mathrm{~B}^{*}$ & $69.0 \mathrm{~B}^{*}$ & $88.0 \mathrm{~A}^{*}$ & $10.4 \mathrm{~A}^{*}$ & $74 \mathrm{~B}^{*}$ & $122.0 \mathrm{~A}$ \\
Glyphosate & $62.0 \mathrm{~B}^{*}$ & $61.0 \mathrm{~B}^{*}$ & $77.0 \mathrm{C}^{*}$ & $8.5 \mathrm{C}^{*}$ & $59.0 \mathrm{C}^{*}$ & $123.0 \mathrm{~A}$ \\
Paraquat & $78.0 \mathrm{~A}$ & $77.0 \mathrm{~A}$ & $92.0 \mathrm{~A}^{*}$ & $10.8 \mathrm{~A} *$ & $80 \mathrm{~A}$ & $130.5 \mathrm{~A}$ \\
Diquat & $69.0 \mathrm{~B}^{*}$ & $65.0 \mathrm{~B}^{*}$ & $80.0 \mathrm{C}^{*}$ & $9.2 \mathrm{~B}$ & $71.0 \mathrm{~B}^{*}$ & $128.0 \mathrm{~A}$ \\
Glufosinate- ammonium & $69.0 \mathrm{~B}^{*}$ & $64.0 \mathrm{~B}^{*}$ & $85.0 \mathrm{~B}$ & $9.7 \mathrm{~B}$ & $71.0 \mathrm{~B}^{*}$ & $126.0 \mathrm{~A}$ \\
\hline Control & 81.0 & 78.0 & 84.0 & 9.5 & 82.0 & 120.0 \\
\hline CV $(\%)$ & 10.9 & 12.05 & 6.98 & 7.43 & 10.6 & 7.87 \\
\hline
\end{tabular}

*different from the control treatment by the Dunnett's test $(p<0.05)$. Means followed by the same letter in the columns are not different by the Scott-Knott test $(p<0.05)$.

The glufosinate-ammonium and saflufenacil herbicides negatively affected the GE, FGC, and AA of the treatments, when compared to the control. Despite these negative results, the treatment with saflufenacil presented higher EM and ESI than the control (Table 4).

Tavares et al. (2016) evaluated the effect of different herbicides applied at pre-harvest on seed quality of adzuki bean (Vigna angularis) and found negative effects of glyphosate and glufosinateammonium on seed germination and vigor after six months of storage. These herbicides may have been translocated to seeds still in formation, since they were sprayed directly on the pods, which are located above the leaves, negatively affecting their quality.

Positive results were found for the use of carfentrazone-ethyl, flumioxazin, and paraquat when compared to the control treatment (Table 4). These herbicides did not affect the physiological potential of the seeds after six months of storage, and some variables showed better results than those of the control. Tavares et al. (2016) found that paraquat and flumioxazin had no effect on the physiological quality of azuki bean seeds after six months of storage. However, Santos et al. (2005) reported that the use of carfentrazone-ethyl as desiccant at preharvest of common bean seeds compromises the physiological potential of stored seeds.

Regarding the effect of the herbicides on the physiological potential of the cowpea seeds, the herbicides carfentrazone-ethyl, flumioxazin, and paraquat resulted in higher seed germination and vigor than the other herbicides. The use of the herbicides saflufenacil, diquat, and glufosinateammonium resulted in seeds with intermediate physiological potential. The results of some variables 
for the glyphosate herbicide were lower than those found for the other herbicides used (Table 4).

The effect of the storage environments on the quality of seeds were significant for EM, ESI, and EC (Table 5). The storage of seeds in the cold controlled environment room resulted in higher seedling emergence percentages and emergence speed index than the storage in the not-controlled environment room; and a lower release of exudates was found for seeds stored in the not-controlled environment. Marcos Filho and Vieira (2009) reported that the results of this test can be affected by several factors and require careful monitoring to assure consistency. These factors include water content, genotype, size, and physical condition of seeds, water volume and dimensions of containers used for imbibition, water quality, precision of the conductivity meter, sample size, imbibition time, temperature during imbibition, and reading procedures.

Table 5. Germination (GE), first germination counting (FGC), emergence (EM), emergence speed index (ESI), and accelerated aging (AA), and electrical conductivity (EC) of cowpea seeds of the cultivar BRS-Tumucumaque after six months of storage under controlled and not-controlled environment rooms.

\begin{tabular}{ccccccc}
\hline $\begin{array}{c}\text { Storage } \\
\text { environment }\end{array}$ & $\begin{array}{c}\text { GE } \\
(\%)\end{array}$ & $\begin{array}{c}\text { FGC } \\
(\%)\end{array}$ & $\begin{array}{c}\text { EM } \\
(\%)\end{array}$ & ESI & $\begin{array}{c}\text { AA } \\
(\%)\end{array}$ & $\begin{array}{c}\text { EC } \\
\left(\mu \mathrm{cm}^{-1} \mathrm{~g}^{-1}\right)\end{array}$ \\
\hline Controlled & $76.0 \mathrm{~A}$ & $73.0 \mathrm{~A}$ & $91.0 \mathrm{~A}$ & $10.3 \mathrm{~A}$ & $73.0 \mathrm{~A}$ & $128.5 \mathrm{~B}$ \\
Not-controlled & $72.0 \mathrm{~A}$ & $71.0 \mathrm{~A}$ & $79.0 \mathrm{~B}$ & $9.3 \mathrm{~B}$ & $76.0 \mathrm{~A}$ & $117.3 \mathrm{~A}$ \\
\hline
\end{tabular}

Means followed by the same letter in the columns are not different by the Scott-Knott test $(p<0.05)$

\section{CONCLUSIONS}

The physiological quality of cowpea seeds of the cultivar BRS-Tumucumaque at post-harvest period and after six months of storage was not affected by the carfentrazone-ethyl and flumioxazin herbicides.

Paraquat and diquat were the most efficient herbicides for the anticipation of harvest ( 9 days) of cowpea seeds.

Glyphosate and glufosinate-ammonium were the most harmful herbicides to the physiological quality of cowpea seeds.

The controlled environment room was the most adequate environment for conservation of cowpea seeds.

\section{ACKNOWLEDGEMENTS}

The authors thank the Brazilian Coordination for the Improvement of Higher Education Personnel (CAPES; code 001), the Foundation for Research Support of the State of Minas Gerais (FAPEMIG), and the Brazilian National Council for Scientific and Technological Development (CNPq) for financing this project.

\section{REFERENCES}

ASSIS, M. O. et al. Pre-harvest desiccation in productivity and physiological quality of Cowpea seeds. Planta daninha, 37: 1-11, 2019.
BRASIL. Ministério da Agricultura, Pecuária e Abastecimento. Regras para análise de sementes. Ministério da Agricultura, Pecuária e Abastecimento. Secretaria de Defesa Agropecuária. Brasília: MAPAACS, 2009. 395 p.

BRASIL. Ministério da Agricultura, Pecuária e Abastecimento. Instrução Normativa $n^{\circ} \mathbf{4 5}$, de 17 de setembro de 2013. Estabelece normas específicas e os padrões de identidade e qualidade para a produção e comercialização de sementes. Brasília, Diário Oficial da República Federativa do Brasil, vol. 150, n. 183, p 36-37. Seção 1. 2013. Disponível em: http://www.lex.com.br/ legis 24861657 INSTRUCAO NORMATIVA N 45_DE_17_DE_SETEMBRO_DE_2013.aspx. Acesso em: 30 de abr. 2020.

BRASIL. Ministério da Agricultura, Pecuária e Abastecimento. Resolução de diretoria colegiada rdc $\mathbf{n}^{\mathbf{0}}$ 190, de 30 de novembro de 2017. 2017. Disponível em: http://portal.anvisa.gov.br/ documents/10181/2871639/RDC 1902017 .pdf/ eb2f6c7f-c965-4e76-bed9-ea9842e $48 \bar{b} 5 \mathrm{c}$. Acesso em: 19 de jun. 2019.

BOTELHO, F. J. E. et al. Qualidade de sementes de soja obtidas de diferentes cultivares submetidas à dessecação com diferentes herbicidas e épocas de aplicação. Revista Agro@mbiente, 10: 137-144, 2016.

DALTRO, E. M. F. et al. Aplicação de dessecantes em précolheita: efeito na qualidade fisiológica de sementes de soja. Revista Brasileira de Sementes, 31: 111-122, 2010 . 
DOMINGOS, P. et al. Qualidade da semente de feijão afetada por dessecantes, em quatro estádios de aplicação. Revista Brasileira de Sementes, 19: 275$282,1997$.

DUTRA, A. S.; TEÓFILO, E. M. Envelhecimento acelerado para avaliar o vigor de sementes de feijão caupi. Revista brasileira de sementes, 29: 193-197, 2007.

DUTRA, A. S. et al. Condutividade elétrica em sementes de feijão caupi. Revista Ciência Agronômica, 37: 166-170, 2006.

FERREIRA, E. A. et al. Translocação do glyphosate em biótipos de azevém (Lolium multiflorum). Planta Daninha, 24: 365-370, 2006.

FREIRE FILHO, F. R. et al. A cultura: Aspectos socioeconômicos. In: VALE, J. C.; BERTINI, C.; BORÉM, A (Eds.). Feijão-caupi: do plantio à colheita. Viçosa, MG: UFV, 2017. cap. 1, p. 9-34.

GUIMARÃES, V. F. et al. Produtividade e qualidade de sementes de soja em função de estádios de dessecação e herbicidas. Planta Daninha, 30: 567 573, 2012.

HE, Y. Q. et al. Effects of pre-harvest chemical application on rice desiccation and seed quality. Journal of Zheijang University Science, 16: 813$823,2015$.

HUBNER JUNIOR, S.; TOLEDO, M. Z. Viabilidade de sementes de feijão-caupi colhidas em diferentes épocas em áreas dessecadas em précolheita. Revista eletrônica da faculdade de ciências exatas e da terra - produção/construção e tecnologia, 5: 75-85, 2016.

HESS, F. D. Light-dependent herbicides: an overview. Wend Science, 48: 160-170, 2000.

INSTITUTO NACIONAL DE METEOROLOGIA INMET. Estação Meteorológica de Observação de Superfície Automática, Viçosa, MG, Brasil. 2018.

JASKULSKI, D.; JASKULSKA, I. The effect of pre -harvest glyphosate application on grain quality and volunteer winter wheat. Romanian Agricultural Research, 31: 283-289, 2014.

KAPPES, C. et al. Qualidade fisiológica de sementes e crescimento de plântulas de feijoeiro, em função de aplicações de Paraquat em pré-colheita. Pesquisa Agropecuária Tropical, 42: 9-18, 2012.

LACERDA, A. L. S. et al. Aplicação de dessecantes na cultura da soja: antecipação da colheita e produção de sementes. Planta Daninha, 19: 381-
390,2001

LACERDA, A. L. S. et al. Armazenamento de sementes de soja dessecadas e avaliação da qualidade fisiológica, bioquímica e sanitária. Revista Brasileira de Sementes, 25: 97-105, 2003.

LACERDA, A. L. S. et al. Efeitos da dessecação de plantas de soja no potencial fisiológico e sanitário das sementes. Bragantia, 64: 447- 457, 2005.

LAMEGO, F. P. et al. Pre-Harvest Application and Effects on Yield and Physiological Quality of Soybean Seeds. Planta Daninha, 31: 929-938, 2013.

MAGUIRE, J. D. Speed of germination-aid in selection and evaluation for seedling emergence and vigour. Crop Science, 2: 176-177, 1962.

MARCANDALLI, L. H. et al. Épocas de aplicação de dessecantes na cultura da soja: Qualidade fisiológica de sementes. Revista Brasileira de Sementes, 33: 241-250, 2011.

MARCOS FILHO, J. Seed vigor testing: an overview of the past, present and future perspective. Scientia Agricola, 72: 363-374, 2015.

MARCOS FILHO, J.; VIEIRA, R. D. Seed vigor tests: procedures - conductivity tests. In: BAALBAKI, R. et al (Eds.). Seed vigor tests handbook. Ithaca, Nova YorK, USA: AOSA, 2009. cap. 7 , p. $186-200$.

MARTINI, G. et al. Eficácia do herbicida glifosatopotássico submetido à chuva simulada após a aplicação. Bragantia, 62: 39-45, 2003.

MCNAUGHTON, K. E. et al. Effect of application timing of glyphosate and saflufenacil as desiccants in dry edible bean (Phaseolus vulgaris L.). Canadian journal of plant science, 95: 369-375, 2015.

NOGUEIRA, N. W. et al. Physiological maturation of cowpea seeds. Journal of Seed Science, 36: 312 317,2014

OLIVEIRA, I. J. et al. BRS Tumucumaque: cultivar de feijão-caupi com valor nutritivo para o Amazonas. 1. ed. Manaus, AM: Embrapa Amazônia Ocidental, 2014. 4 p. (Comunicado técnico, 106).

OLIVEIRA JÚNIOR, R. S. Mecanismos de ação de herbicidas. In: OLIVEIRA JÚNIOR, R. S.; CONSTANTIN, J.; INOUE, M. H. (Eds.). Biologia e manejo de plantas daninhas. Curitiba, PR: Omnipax Editora, 2011. cap. 7, p. 141-192.

PELÚZIO, J. M. et al. Influência da dessecação química e retardamento de colheita na qualidade 
fisiológica de sementes de soja no sul do Estado do Tocantins. Bioscience Journal, 24: 77- 82, 2008.

ROCHA, M. M. et al. Cultivares. In: Do Vale J. C.; BERTINI, C.; BORÉM, A. (Eds.) Feijão-caupi: do plantio à colheita. Viçosa, MG: UFV, 2017. cap. 6, p. 113-142.

SANTOS, F. L. et al. A influência de dessecante na qualidade fisiológica de sementes de soja. Revista Brasileira de Engenharia de Biossistemas, 12: 6876, 2018.

SANTOS, J. B. et al. Efeitos da dessecação de plantas de feijão sobre a qualidade de sementes armazenadas. Planta Daninha, 23: 645-651, 2005.

SILVA, A. A. et al. Herbicidas: classificação e mecanismos de ação In: SILVA, A. A.; SILVA, J. F. (Eds). Tópicos em Manejo de Plantas Daninhas. Viçosa, MG: UFV, 2007. cap. 3, p. 83-148.

TAVARES, C. J. et al. Physiological and sanitary quality of desiccated and stored azuki bean seeds. Revista Caatinga, 29: 66-75, 2016.

TERASAWA, J. M. et al. Antecipação da colheita na qualidade fisiológica de sementes de soja. Bragantia, 68: 443-448, 2009.

TOLEDO, M. Z. et al. Dessecação em pré-colheita com glifosato e qualidade de sementes armazenadas de soja. Semina: Ciências Agrárias, 35: 765-774, 2014.

TORRES, L. G. et al. Alterações nas características fisiológicas de cultivares de cana-de-açúcar submetida à aplicação de herbicidas. Planta Daninha, 30: 581-587, 2012.

ZHANG, T. et al. Evaluation of harvest aid herbicides as desiccants in lentil production. Weed Technology, 30: 629-638, 2016

ZUFFO, A. M. et al. A dessecação química e a época de colheita afetam a qualidade fisiológica e sanitária de sementes de soja? Revista Caatinga. 32: 934$942,2019$. 